Article

\title{
European Green Deal and Recovery Plan: Green Jobs, Skills and Wellbeing Economics in Spain
}

\author{
Martín García Vaquero ${ }^{1,2, *}$, Antonio Sánchez-Bayón ${ }^{3, *(D)}$ and José Lominchar 4 \\ 1 Foro Innovación, 28042 Madrid, Spain \\ 2 Department of Management, EAE Business School, 28002 Madrid, Spain \\ 3 Department of Business Economics (ADO), Applied Economics II and Fundamentals of Economic Analysis, \\ Legal and Social Sciences School, Rey Juan Carlos University, 28033 Madrid, Spain \\ 4 Department of Law \& Social Sciences, Universidad a Distancia de Madrid (UDIMA), Collado Villalba, \\ 28400 Madrid, Spain; Jose.lominchar@udima.es \\ * Correspondence: martingarciavaquero@gmail.com (M.G.V.); antonio.sbayon@urjc.es (A.S.-B.)
}

Citation: García Vaquero, M.;

Sánchez-Bayón, A.; Lominchar, J.

European Green Deal and Recovery

Plan: Green Jobs, Skills and Wellbeing

Economics in Spain. Energies 2021, 14,

4145. https://doi.org/10.3390/

en14144145

Academic Editor: Almas Heshmati

Received: 7 June 2021

Accepted: 1 July 2021

Published: 9 July 2021

Publisher's Note: MDPI stays neutral with regard to jurisdictional claims in published maps and institutional affiliations.

Copyright: (c) 2021 by the authors. Licensee MDPI, Basel, Switzerland. This article is an open access article distributed under the terms and conditions of the Creative Commons Attribution (CC BY) license (https:// creativecommons.org/licenses/by/ $4.0 /)$.

\begin{abstract}
This paper on Political Economic and Labour Economic Policies in the European Green Deal framework analyses the Recovery Plan and Resilience Facility. It pays attention to the effects on the design of new green jobs and the necessary skills to develop this type of new positions generated, with higher labour wellbeing. The paper is focused on the analysis of the green jobs' opportunity for Europe, at a country level, with a specific analysis made for the Spanish case. A systematisation of the concepts and calculations on the issue is made and analysed (attending the international institutions and forums proposals) to harmonise the recovery plans, apply them beyond the energy sector to other related green activities and align the public and private sector, and other critical stakeholders, in achieving this goal. The following research questions were formulated: (1) what is the estimated number of new green jobs that would be created as a consequence of the implementation of the Recovery Plan in Spain; (2) which new soft skills or re-skilling would be necessary to develop such new green jobs; (3) how much are the new jobs aligned with Wellbeing Economics? The research was conducted by applying a few research methods, i.e., secondary sources, the desk research method and the exploration method, critical and comparative analysis, inductive and deductive reasoning and some mathematical calculations. The research contribution can provide a valuable source of information to coordinate sectoral plans by the policymakers, particularly those responsible for the economy, business, green activities and education.
\end{abstract}

Keywords: Labour Economic Policies; European Green Deal; Recovery Plan; green jobs; skills; Wellbeing Economics

\section{Introduction}

In the last few years, many international institutions and forums committed to realising a climate-neutral economy of wellbeing (beyond the welfare state economy model): a model of satisfaction based on a balance relation of people-planet-profit [1]. For example, the UN SGD agenda for Horizon 2030 [2,3], the economy of the wellbeing of the OECD [4], the Wellbeing Economy Alliance of WEF and the net of trans-national corporations [5], the EU Green Deal [6] and others. The EU Green Deal was approved officially in 2019 [7], for the Multiannual Financial Framework 2021-2027 [8], to promote clean energy production [9], smart cities and the wellbeing of business and professionals in Europe [10]. With the black swan [11] of the COVID-19 crisis and its management [12,13], there is an opportunity to implement actual recovery plans aligned with the Green Deal. Currently, in the EU, there has been a shock on employment rates, for this reason, the European Commission is reinforcing its commitment to green and sustainable growth with the Recovery Plan for Europe [14], funded with EUR 1.8 trillion, designed to put the recovery on track by the path of the European Green Deal. 
In this context, it is worth mentioning the importance of Regulation (EU) 2021/241signed by the co-legislators on 12 February 2021—setting up the Recovery and Resilience Facility (RRF).

The RRF aims to offer financial support for those public investments and reforms. It is seen as a key programme of the EU Recovery Instrument (NextGenerationEU) in the framework of the revised Multiannual Financial Framework (MFF) for 2021-2027. It includes the provision: "of non-repayable financial support and loans to the Member States to support public investments and reforms, as set out in their National Recovery and Resilience Plans (NRRPs)". These "loans complement non-repayable support and are to be proposed in exchange for additional reforms and investments beyond those that benefit from the non-repayable financial support" [15].

This proposal takes as a basis and replaces a previous proposal on establishing a Reform Support Programme, which is withdrawn. The proposal establishing a governance framework for the Budgetary Instrument for Convergence and Competitiveness for the Euro area (BICC) is also withdrawn as a result.

The initiative was tabled by the European Commission on 28 May 2020. The Council of the European Union adopted its general approach concerning this proposal on 9 October 2020. The European Parliament's relevant committees adopted a negotiating position on 9 November. An informal agreement between the co-legislators concerning this initiative was reached on 18 December. This was formally endorsed by the Parliament's plenary on 10 February 2021 and on the following day by the Council. The Act was signed on 12 February 2021 and published in the Official Journal on 18 February 2021.

On 20 May 2021, the plenary of the European Parliament adopted a Resolution urging the European Commission to send MEPs all relevant information on national recovery efforts for the sake of democratic oversight, as established in the RRF Regulation.

Furthermore, over the last few months, there are the following several fronts in progress: the proposal and launch in some countries of the Climate Law [16-18], the "development of a sustainable blue economy in the EU for the industries and sectors related to oceans, seas, and coasts" $[19,20]$, the strategy towards zero pollution for air, water and soil [21], or the Organic action plan [22], to produce high-quality food with low environmental impact and organic farming trough farm to fork strategy.

The EU Green Deal and the EU Recovery Instrument (NextGenerationEU) is an ample opportunity for the European Union. However, to turn it into a success, it must be firmly based on the fundamental pillars of the EU system, particularly the concepts of solidarity, sustainable and wellbeing development, environmental protection and labour relations generation. In the European Union, the Recovery Plan for Europe as well as the National Plans for each country can, therefore, enable member states to reap the full benefits of the green transition on the economy and employment, with the creation of new green jobs, stable, predictable and resilient economic growth and less pollution with healthier and cleaner air. In this context, this paper analyses the green jobs generation in Spain and the Spanish National Recovery and Resilience Plan or "Plan de Recuperación, Transformación y Resiliencia" [15,16].

\section{Literature Review}

\subsection{Green Jobs}

This paper is an analytical study of Political Economy and a study of Economic Policies (with the historical and comparative method). This paper assumes the changes in reality and its paradigm with globalisation [1] and its reformulation from international institutions and comparative and global solutions [23].

The International Labour Organization (ILO) is part of the universal system of the United Nations, and it has the responsibility to establish the general standards in labour relations in the world [24]. The ILO promotes green jobs as part of decent work (an ILO project on the future of the work). In this way, green jobs are connected with sustainable development, people wellbeing and healthy organisations. The ILO adopted some recom- 
mendations in green jobs during the 102nd ILC in 2013. Later, it passed the Guidelines for a just transition towards environmentally sustainable economies and societies for all, adopted in November of 2015, by the ILO Governing Body [24]. The ILO defines green jobs as "decent jobs that contribute to preserve or restore the environment, be they in traditional sectors such as manufacturing and construction or in new, emerging green sectors such as renewable energy and energy efficiency" [17]. In general, "green jobs help improve energy and raw materials efficiency, limit greenhouse gas emissions, minimise waste and pollution, protect and restore ecosystems, and support adaptation to climate change" [17]. Additionally, the ILO goes beyond this, and it connects green jobs with other fields, supporting the research of many scientists and scholars (see Figure 1).

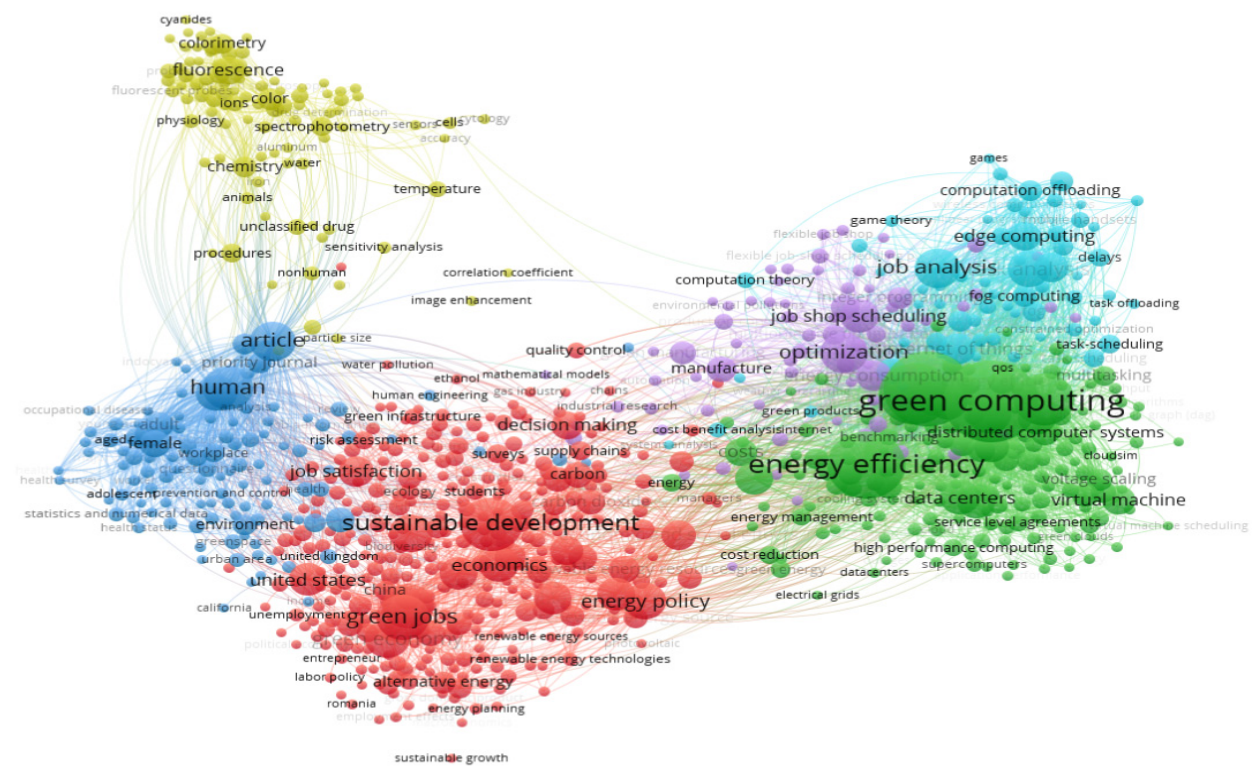

Figure 1. Green jobs, wellbeing and other fields connected. Source: own elaboration with data from Scopus articles (2017-2021) using VOS viewer [25].

There are other dimensions to extend the concept of the green job since the definition is not uniform [26]. Various papers provide different aspects to set up the boundaries of green jobs, more specifically, using the type of industry, the production methods and the specific jobs with the associated skills and abilities [26-29]. Additionally, statistical offices recognise the challenge to define green jobs [30], and they harmonise the definition into the Environmental Goods and Services Sector (EGSS), describing it in terms of many created jobs and generated value-added, identifying the green jobs associated with the EGSS [31]. There is also a classification provided by the US Department of Labour [32,33]. This entity establishes the occupations that have been identified as "Green," being the following green occupational categories assigned to the professions in the way that they classify in: Green New and Emerging, Green Enhanced Skills and Green Increased Demand, depending on the level and type of impact of the green economy activities and technologies in the work requirements and employment demand. An example of the most relevant green jobs in the USA, and their foreseen evolution, are shown in Table 1.

One general approach to simplifying the definition of green jobs is related to the sectors and skilled workforce that produce goods or services that help to protect the environment, the natural resources and develop new technologies and processes that could stop or revert the effects of climate change. Regarding the skills necessary to execute a green job, some works [21,22] highlight the importance of having different skills adapted to perform the green tasks.

In particular, it highlights the fact that "employed persons in jobs with high green potential are, on average, younger, more often men, have a higher level of educational attainment and a higher probability of having immigrated than employed persons in other 
occupations. There is a need and shortage of skilled labour force in the group of jobs with high green potential, which is especially notable for the groups of managers and professionals" [21]. With the arrival of the Green Recovery Plans, a rise in the job demand for green jobs is expected [22]. Hence, specific efforts in labour skills related to this field (mainly education at all levels and skills upgrading) should be implemented in all countries to reach the demand for skilled specialists. These efforts will help the necessary and rapid adaptation to the new sustainable economy caused by the pandemic and the subsequent work crisis.

Table 1. Green jobs in USA, 2021. Source: own elaboration based on data from O*NET [34].

\begin{tabular}{|c|c|c|c|}
\hline Green Jobs USA as of May 2021 & $\begin{array}{l}\text { Employment } \\
\text { (2019) }\end{array}$ & $\begin{array}{c}\text { Projected Job Openings } \\
(2019-2029)\end{array}$ & Projected Growth (2019-2029) \\
\hline Sustainability Specialists & $1,316,800$ & 128,000 & much faster than average ( $8 \%$ or higher) \\
\hline $\begin{array}{c}\text { Landscaping and Groundskeeping } \\
\text { Workers }\end{array}$ & $1,188,000$ & 158,900 & much faster than average ( $8 \%$ or higher) \\
\hline $\begin{array}{c}\text { First-Line Supervisors of Production and } \\
\text { Operating Workers }\end{array}$ & 648,900 & 56,900 & little or no change \\
\hline $\begin{array}{c}\text { Inspectors, Testers, Sorters, Samplers and } \\
\text { Weighers }\end{array}$ & 590,100 & 48,300 & decline $(-1 \%$ or lower $)$ \\
\hline Plumbers, Pipefitters and Steamfitters & 490,200 & 49,800 & average $(3-4 \%)$ \\
\hline Financial and Investment Analysts & 487,800 & 38,600 & Faster than average \\
\hline $\begin{array}{l}\text { Training and Development Specialists } \\
\text { Sales Rep., Wholesale and }\end{array}$ & 327,900 & 33,700 & much faster than average ( $8 \%$ or higher) \\
\hline $\begin{array}{c}\text { Manufacturing, Tech and Scientific } \\
\text { Products }\end{array}$ & 321,000 & 30,700 & average $(3-4 \%)$ \\
\hline Mechanical Engineers & 316,300 & 19,200 & average $(3-4 \%)$ \\
\hline Chief Sustainability Officers & 287,900 & 13,900 & decline $(-1 \%$ or lower $)$ \\
\hline Production Workers, All Other & 238,600 & 24,700 & slower than average $(1-2 \%)$ \\
\hline Energy Engineers, Except Wind and Solar & 170,100 & 10,300 & slower than average $(1-2 \%)$ \\
\hline Architects, Except Landscape and Naval & 129,900 & 8700 & slower than average $(1-2 \%)$ \\
\hline $\begin{array}{l}\text { Mixing and Blending Machine Setters, } \\
\text { Operators and Tenders }\end{array}$ & 128,000 & 13,300 & slower than average $(1-2 \%)$ \\
\hline $\begin{array}{c}\text { Career/Technical Education Teachers, } \\
\text { Postsecondary }\end{array}$ & 124,100 & 9400 & slower than average $(1-2 \%)$ \\
\hline Industrial Ecologists & 90,900 & 8900 & much faster than average ( $8 \%$ or higher) \\
\hline Machine Feeders and Offbearers & 62,900 & 7000 & little or no change \\
\hline $\begin{array}{l}\text { Separating, Filtering, Clarifying, } \\
\text { Precipitating, Operators and Tenders }\end{array}$ & 53,100 & 5400 & average $(3-4 \%)$ \\
\hline Materials Engineers & 27,500 & 1500 & slower than average $(1-2 \%)$ \\
\hline Foundry Mold and Coremakers & 17,600 & 1400 & decline $(-1 \%$ or lower $)$ \\
\hline
\end{tabular}

\subsection{Green Growth}

Green growth and green development concepts and policies are increasing in interest over the last few years. International entities such as the Organization for Economic Cooperation and Development (OECD), the World Bank, the European Commission (EC) or the United Nations Environmental Program (UNEP), among other institutions, have had several initiatives on the subject.

The OECD definition of green growth is "about fostering economic growth and development while ensuring that natural assets continue to provide the resources and environmental services on which our wellbeing relies. It is also about fostering investment and innovation, which will underpin sustained growth and give rise to new economic opportunities" [35].

On the other hand, the EC, explicitly says, "The aim is to create more value while using fewer resources, and substituting them with more environmentally favourable choices wherever possible" [36]. Meanwhile, the World Bank states: "Green growth is growth that is efficient in its use of natural resources, clean in that it minimises pollution and environmental impacts, and resilient in that it accounts for natural hazards" [37]. 
The United Nations Environmental Program (UNEP) defines a green economy as "the economy that improves human wellbeing and social equity, while significantly reducing environmental risks and ecological scarcities" [38].

None of the above definitions establishes measurable and scientific criteria for what is considered green growth. Accurate and simple indicators are needed to decide whether economic growth is green enough to allow countries to fit within the parameters set for meeting climate change targets. There is criticism over those traditional approaches to the definition, which says that it is a traditional economic growth model with a different label.

Ultimately, and based on decoupling theory, a definition of green growth has been accepted: "Green growth is an increase in economic output that lowers total environmental footprint" $[39,40]$.

On this point, an intense debate is taking place between advocates of green growth and opponents of it [41-47]. Although in the last decade, the dominant thinking has been that of green growth in policymaking, whether at the country level or in the UN context, the EU or other world institutions. The underlying argument is the assumption that decoupling environmental pressures from the gross domestic product could enable endless economic growth. Numerous studies review the strength of the scientific rationale supporting the decoupling hypothesis and come to shocking conclusions. There is no empirical evidence to justify decoupling economic growth and environmental pressures to cope with environmental collapse. On the other hand, and more importantly, it seems unlikely that such decoupling can become a reality shortly.

The current policy strategies aimed at increasing growth must consider the quest for sufficiency, reducing economic output in many sectors and, thus, reducing consumption on a global scale. These factors will make life sustainable within the ecological limits of the planet.

\subsection{Green Jobs, Technovation and Wellbeing}

The new economic paradigm is based on optimising a triple-P-relation among profitsplanet-people, supported by several international commitments $[4,5]$. This relation is based on technological advances or technovation to increase global wealth, protect nature and improve the world's living standards, which means wellbeing for humankind [1,10]. The former paradigm, the Welfare State Economic, was materialistic and focused on measuring the GDP. However, the emergent paradigm, Wellbeing Economics (WBE) (which includes several steps of the digital economy, i.e., collaborative and circular economy, orange economy), is more immaterial (i.e., virtual relations using the internet, psychological and spiritual worries) and is focused on the happiness pursuit (from 2012, it is measured each year by the UN) $[25,48,49]$. The realisation of WBE for Horizon 2030 will mean the following several transitions: the end of the fourth industrial and technological revolution and the beginning of the fifth revolution [1,25,50]; the fall of industrial and development capitalism and the rise of talent capitalism [51,52], among others.

\section{Methodology}

The research was conducted by applying a few research methods, i.e., secondary sources, the desk research method and the exploration method, critical and comparative analysis, inductive and deductive reasoning and some mathematical calculations (see Figure 2).

The methodology used to obtain the final data and conclusions has followed a threestage approach (see Figure 2). Firstly, a search for the most updated documentation about Recovery Plans and the in-depth analysis of the Spanish Plan [16], including renewable and other specific programmes $[18,53,54]$, using the data provided by the International Energy Agency (IEA) and the International Monetary Fund in the World Energy Outlook [55-57], in which they use the "employment multipliers" and "input-output model" approach that makes an estimation of how many jobs are generated per million euros invested. Secondly, according to the OECD and other sources, an identification of the primary 
skills is observed [35,56-58] and the existing gap between Spain and other European countries [59-61]. As a result, it has laid the foundations for subsequent analysis to identify the specific green skills needed in the country. Lastly, in the conclusion section, the most relevant points, the study's limitations and some future research lines (i.e., to measure the wellbeing in the new jobs) are highlighted.

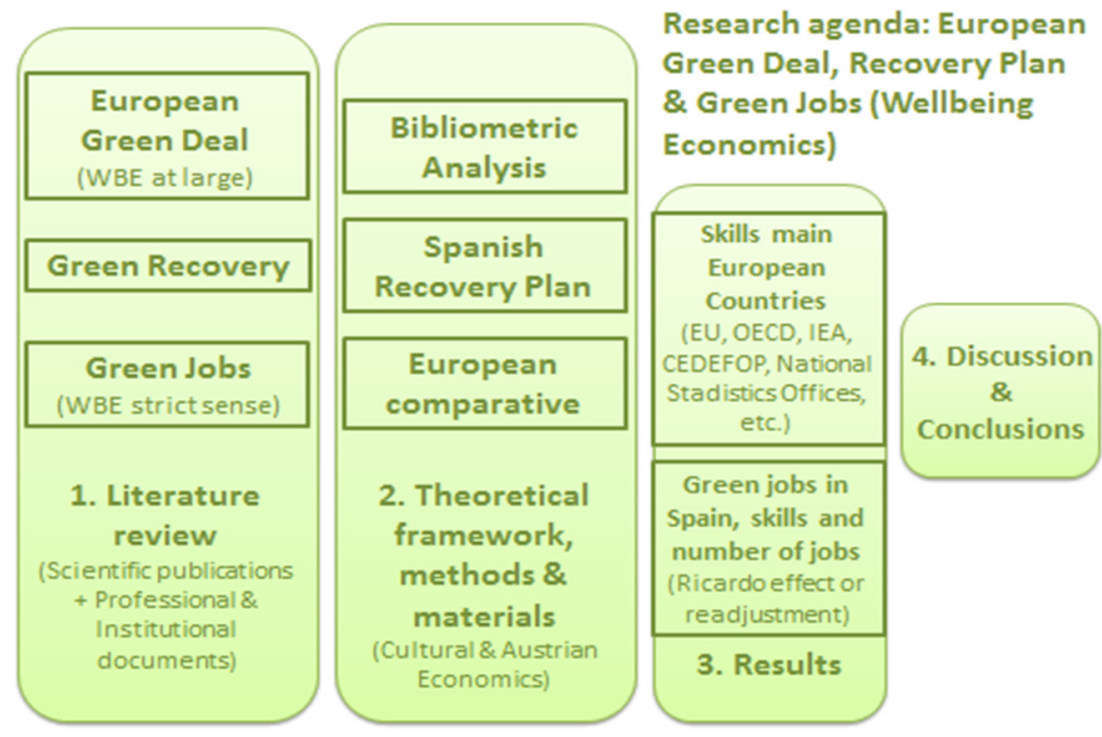

Figure 2. Structure and methodology (research plan). Source: own elaboration.

\section{Green Jobs Generation}

\subsection{Macroeconomics View}

\subsubsection{An Overview}

The Spanish Recovery Plan "envisages the mobilisation of more than 140 billion euros in public investment until 2026" [16], "with a significant concentration of investments and reforms in the first phase of the Plan" [6,8], covering the 2021-2023 period, "to boost recovery and achieve the greatest possible countercyclical impact". Given the high level of uncertainty about some crucial variables, the Plan gives more essential details for the first phase, including the mobilisation of nearly " 69.52 billion euros in transfers from the European Recovery and Resilience Facility" [18,53].

The "plan assigns $40.29 \%$ of investments for promoting the green transition, and $29.58 \%$ for the digital transformation, in precise alignment with the UN SDG 2030 Agenda [3] and with the specific recommendations of the EU institutions" [18,53].

\subsubsection{Cross-Cutting Lines of Action for a Green Spain}

Although the Spanish Recovery Plan [16] has four cross-cutting lines of action that serve as the backbone for all the levers and components, we focus our analysis on the green initiatives, the so-called ten lever policies.

Spanish Recovery Plan, Lever policy I: "Urban and rural agenda, agricultural development and the fight against depopulation" [16].

The first lever is the most important in terms of promoting social and rural innovation. The objective is to facilitate the growth and revitalisation of territories in decline, with the implementation of impactful and attractive projects that increase the population, attract qualified professionals and promote the sustainable use of resources. This lever also includes the promotion of sustainable and safe mobility in metropolitan and urban areas as well as the rehabilitation of buildings with a negative impact on the environment. A final aspect on the agri-food and fishing industry, with green, modernisation and digitalisation plans, is also envisaged.

According to the Spanish Recovery Plan [16], the Plan includes the following components in Lever I: 
"1. Plan for safe, sustainable and connected mobility in urban and metropolitan areas

2. Housing rehabilitation and urban renewal plan

3. Green and digital transformation of the agri-food and fisheries industries"

Spanish Recovery Plan, Lever policy II: "Resilient infrastructures and ecosystems" [16].

This block is related to the protection, conservation and restoration of ecodiversity, where water and the protection of coastal areas, of which there are 7268 according to the World Resources Institute, are crucial. This area also deals with sustainable, safe and interconnected mobility. All these concepts make this block an attractive area for private investment.

According to the Spanish Recovery Plan [16], the Plan includes the following components in the Lever II:

"4. Ecosystems and biodiversity conservation and restoration

5. Coastal area and water resources preservation

6. Sustainable, safe and connected mobility"

Spanish Recovery Plan, Lever policy III: “A fair and inclusive energy transition" [16].

Spain has a very high potential for both private and public-private investment and partnerships (PPPs), and for developing the renewable energy industry by making the most of its potential in terms of geographic and climatic conditions.

With a predictable and stable regulatory framework and a green energy sector, the conditions can be in place to increase the country's international competitiveness and allow it to be one of the global leaders in some renewable energy segments, as is already the case with companies that are among the international leaders in the field.

According to Spanish Recovery Plan [16], the Plan includes the following components in the Lever III:

"7. Renewable energies implementation and integration

8. Electrical infrastructures, promotion of intelligent networks and deployment of flexibility and storage

9. Renewable hydrogen roadmap and sectoral integration

10. Fair transition strategy"

A summary of the complete Spanish Recovery Plan [16] can be seen in Table 2, with the previous Lever Policies embedded along with the allocated budget per program and its percentage over the total amount, EUR 69.52 billion for 2021-2023.

The components with an effect on the green transition are analysed (marked in green), and other subchapters not explicitly contemplated in Table 2.

Sustainable and connected mobility strategy (EUR 13.2 billion). The action plan is positive due to its support for zero-emission vehicles. As some of the funding available through this measure will also likely support "low-emission" vehicles, i.e., not best-in-class solutions regarding the green transition, this component is not assessed as very positive. Furthermore, it should be noted that the Plan's funding for the mobility sector is intensely focused on the automotive industry, with little to no support for other mobility solutions.

Plan for housing renovation and urban regeneration (EUR 6.8 billion). Although its final assessment is conditional on presenting specific standards and targets to be achieved through the renovation measures, the action plan is very positive.

Further mobility investments (EUR 6.7 billion), which we assess as positive due to TEN-T rail corridors and sustainable transport, are not as positive due to ambiguities on what will be supported through some measures included in the component.

Investments into renewable energy deployment and integration (EUR 3.2 billion), which we assess as very positive.

A renewable hydrogen roadmap (EUR 1.6 billion) to develop and deploy renewable hydrogen. We assess this measure as very positive due to its focus on renewable hydrogen. However, this assessment is conditional on only renewable hydrogen receiving support, and we note that there are some concerns that non-renewable forms of hydrogen may receive support through this measure, which would necessitate a less favourable assessment. 
Table 2. Recovery plan sections and investments. Source: own elaboration based on data from the Spanish Recovery Plan [16].

\section{Lever Policies and Components}

EUR Billion
2021-2023

14.4

I. Urban and rural agenda, agricultural development and the fight against depopulation

1. Action Plan for sustainable, safe and connected mobility in urban and metropolitan areas

2. Housing rehabilitation and urban renewal plan

3. Green and digital transformation of agri-food and fisheries industries

\section{Resilient infrastructures and ecosystems}

4. Ecosystems and biodiversity conservation and restoration

5. Coastal area and water resources preservation

6. Sustainable, safe and connected mobility

III. A fair and inclusive energy transition

7. Renewable energies implementation and integration

8. Electrical infrastructures, promotion of smart networks and deployment of flexibility and storage

9. Renewable hydrogen roadmap and sectoral integration

10. Fair transition strategy

\section{A public administration for the 21st century}

11. Modernisation of public administration

V. Modernisation and digitalisation of industry and SMEs, entrepreneurship and business environment, recovery and transformation of tourism and other strategic sectors

\begin{tabular}{lcc} 
12. Industrial Policy Spain 2030 & 3.78 & $5.40 \%$ \\
13. Fostering SME growth & 4.89 & $7 \%$ \\
connectivity, cybersecurity, 5G deployment & 3.4 & $4.90 \%$ \\
\hline
\end{tabular}

$\begin{array}{lcc}\text { 14. Modernisation and competitiveness of the tourism sector } & 3.4 & 4.90 \% \\ \text { 15. Digital connectivity, cybersecurity, 5G deployment } & 3.99 & 5.70 \%\end{array}$

VI. Promotion of science and innovation and strengthening of the capabilities of the National Health System

\section{National Strategy for Artificial Intelligence}

17. Institutional reform and capacity building in the national science, technology and innovation system

18. Renewal and expansion of the capabilities of the National Health System

VII. Education and knowledge, lifelong learning and capacity building

19. National Plan for Digital skills

20. Strategic plan for Vocational Training

21. Modernisation and digitalisation of the education system, including early years education from age 0 to 3

\section{The new care economy and employment policies}

22. Emergency plan for the care economy and reinforcement of inclusion policies

23. New public policies for a dynamic, resilient and inclusive labour market

\section{Promotion of the culture and sports industries}

24. Valorization of the cultural industry

25. Spain audio-visual hub

26. Sports industry promotion plan

$X$. Modernisation of the tax system for inclusive and sustainable growth

27. Measures and actions to prevent and combat tax fraud

28. Tax reform for the 21st century

29. Improving the effectiveness of public spending

30. Long-term sustainability of the public pension system within the framework of the Toledo Pact

\section{Total}

Total Green Initiatives
$\%$

$20.70 \%$

$6.53 \quad 9.40 \%$

$6.82 \quad 9.80 \%$

$1.05 \quad 1.50 \%$

$10.4 \quad 15 \%$

$1.64 \quad 2.40 \%$

$2.09 \quad 3 \%$

$6.66 \quad 9.60 \%$

$6.38 \quad 9.20 \%$

$3.16 \quad 4.50 \%$

$1.36 \quad 2 \%$

$1.55 \quad 2.20 \%$

$0.3 \quad 0.40 \%$

$4.31 \quad 6.20 \%$

$4.31 \quad 6.20 \%$

$16.07 \quad 23.10 \%$

$4.94 \quad 7.10 \%$

\begin{tabular}{cc}
0.5 & $0.70 \%$ \\
3.38 & $4.90 \%$ \\
1.06 & $1.50 \%$ \\
\hline $\mathbf{7 . 3 1}$ & $\mathbf{1 0 . 5 0 \%}$ \\
\hline 3.59 & $5.20 \%$ \\
2.07 & $3 \%$ \\
1.64 & $2.40 \%$
\end{tabular}

\begin{tabular}{cc}
$\mathbf{4 . 8 5}$ & $\mathbf{7 \%}$ \\
\hline 2.49 & $3.60 \%$ \\
2.36 & $3.40 \%$ \\
$\mathbf{0 . 8 2}$ & $\mathbf{1 . 2 0 \%}$ \\
\hline 0.32 & $0.50 \%$ \\
0.2 & $0.30 \%$ \\
0.3 & $0.40 \%$ \\
\hline $\mathbf{0}$ & $\mathbf{0 \%}$ \\
\hline 0 & $0 \%$ \\
0 & $0 \%$ \\
0 & $0 \%$ \\
0 & $0 \%$ \\
\hline
\end{tabular}


A Just Transition Strategy (EUR 0.3 billion) will support just transition agreements in energy transition zones and investments in just transition measures. We assess this measure as positive as it makes an indirect, significant contribution to the green transition.

Investments into the industry sector and a 2030 Industry Strategy (EUR 3.8 billion) can be categorised as having a likely climate effect that is not assessable, as the decarbonisation of the industrial sector is the next challenge in the green transition. However, the component itself does not include specific green targets.

Investments in science, technology and innovation (EUR 3.4 billion) are assessed as positive, as the component includes some research projects on environmental topics.

Below, the top 20 programmes regarding mobilising investments and the top 20 reforms of the Spanish Recovery Plan are shown. In this respect, it should be highlighted that the significant reforms-marked in green as very positive-are aligned with green projects and new initiatives (Tables 3 and 4).

Table 3. Recovery plan investments. Source: own elaboration based on data from the Spanish Recovery Plan [16].

\begin{tabular}{cc}
\hline The 20 Programmes Driving Investment & EUR Billion 2021-2023 \\
\hline 1. Safe, sustainable and connected mobility strategy & 13.2 \\
2. Housing rehabilitation and urban renewal programme & 6.82 \\
3. Modernisation of the public administration & 4.31 \\
4. SMEs Digitalisation Plan & 4.06 \\
5. 5G roadmap & 3.99 \\
6. New Spain 2030 industrial policy and circular economy strategy & 3.78 \\
7. National Plan for Digital Skills & 3.59 \\
8. Modernisation and competitiveness of the tourism industry & 3.4 \\
9. Development of the national science and innovation system & 3.38 \\
10. Implementation and integration of renewable energies & 3.16 \\
11. New care economy & 2.49 \\
12. New public policies for a dynamic, resilient and inclusive & 2.36 \\
labour market & 2.09 \\
13. Preservation of coastal areas and water resources & 2.07 \\
14. Strategic plan for vocational training & 1.64 \\
15. Modernisation and digitalisation of the education system & 1.64 \\
16. Conservation and restoration of ecosystems and biodiversity & 1.55 \\
17. Renewable hydrogen roadmap & 1.36 \\
18. Electrical infrastructure, smart networks and storage & 1.06 \\
19. Renovation and modernisation of the health system & 0.5 \\
20. National Strategy for Artificial Intelligence & 69.52 \\
\hline Total Green Initiatives & 36.98 \\
\hline
\end{tabular}

Table 4. Main reforms of the Recovery Plan. Source: own elaboration based on data from the Spanish Recovery Plan [16].

The 20 Main Reforms of the Recovery Plan

1. Climate Change and Energy Transition Law

2. Development of a robust and flexible energy system, implementation and integration of renewable energies

3. Renewable hydrogen roadmap

4. Resilience and adaptation of ecosystems, development and connectivity of green infrastructures

5. Water Law and national water treatment, sanitation, efficiency, saving and reuse plan

6. Modernisation of the agricultural and fisheries policy-soil protection and efficient use of water

7. Waste policy and promotion of the circular economy

8. Modernisation of the national science system and support for innovation

9. Sustainable and connected mobility strategy

10. New housing policy

11. Modernisation of the justice system 
Table 4. Cont.

\section{The 20 Main Reforms of the Recovery Plan}

12. Modernisation and digitalisation of the public administration

13. Better regulation and business environment-insolvency framework reform

14. Modernisation and strengthening of the National Health System

15. Modernisation and strengthening of the education, vocational training and university system 16. New labour market public policies

17. New care economy

18. Reinforcement of inclusion policies and social services

19. Modernisation and progressivity of the tax system

20. Strengthening of the pension system

\subsubsection{Green Recovery Plans-Cross Country View}

To compare good practices in the recovery and resilience plans of various European countries (in the framework of the EU Green Deal $[18,53]$ ), the strengths, as well as the different plans and investment levels of the following countries, have been briefly analysed and described: France, Germany, Portugal and Spain (see Figures 3 and 4). Since, at the time of writing, it was not accessible and possible to make a deep comparative analysis of these countries, we have reproduced the analysis and main conclusions made by the Green Recovery Tracker, E3G and Wuppertal Institute [53-58].

France: Professional pieces of training to support the ecological transition. France reinforces training for the "strategic professions of tomorrow" in line with strategic sectors (digitalisation, environmental change, industrial sectors concerned by economic sovereignty and the relocation of productions) and in line with the priorities of the recovery plan.

Germany: Its recovery plan does not include support measures for the fossil fuel industry, although the large German manufacturers firmly forced the opposite. There are some exceptions for gas engines and new aircraft purchases.

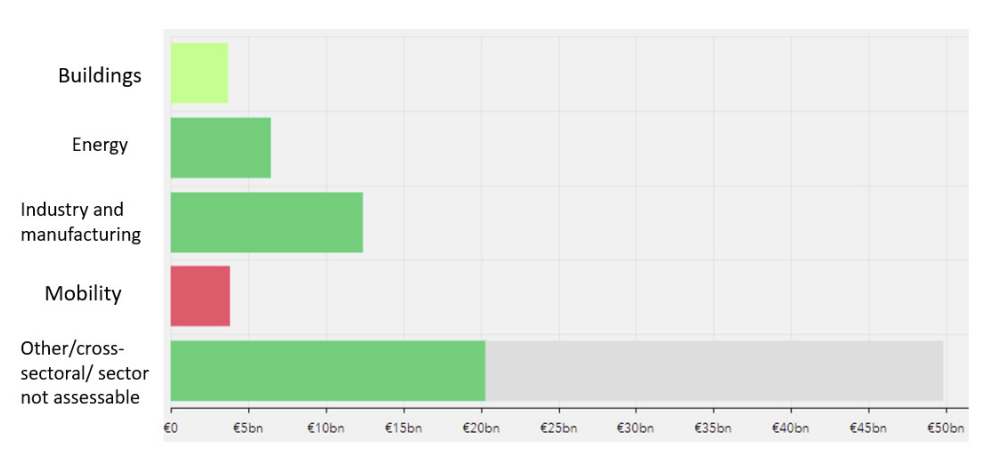

(a)

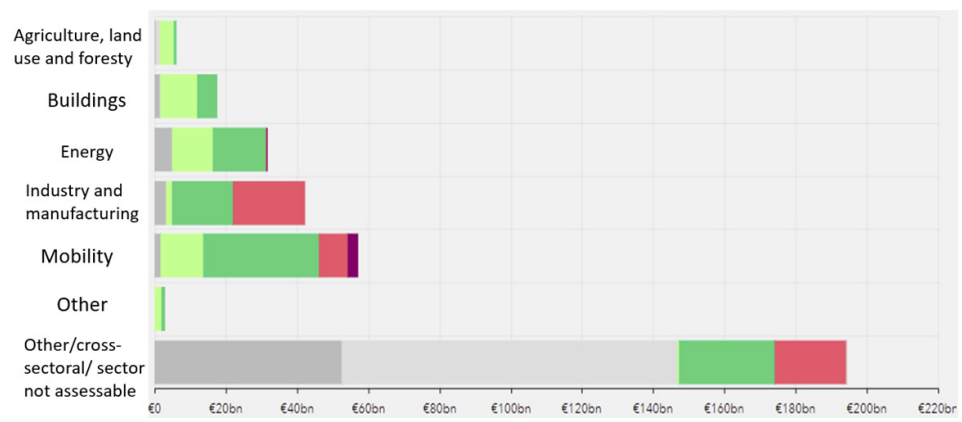

(b)
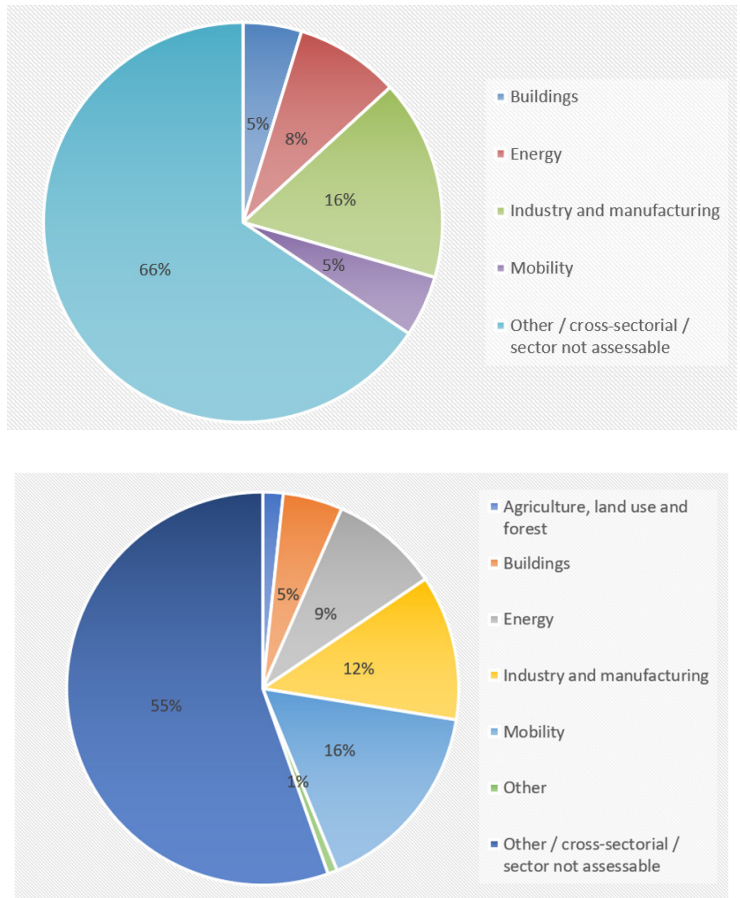

Figure 3. Cont. 

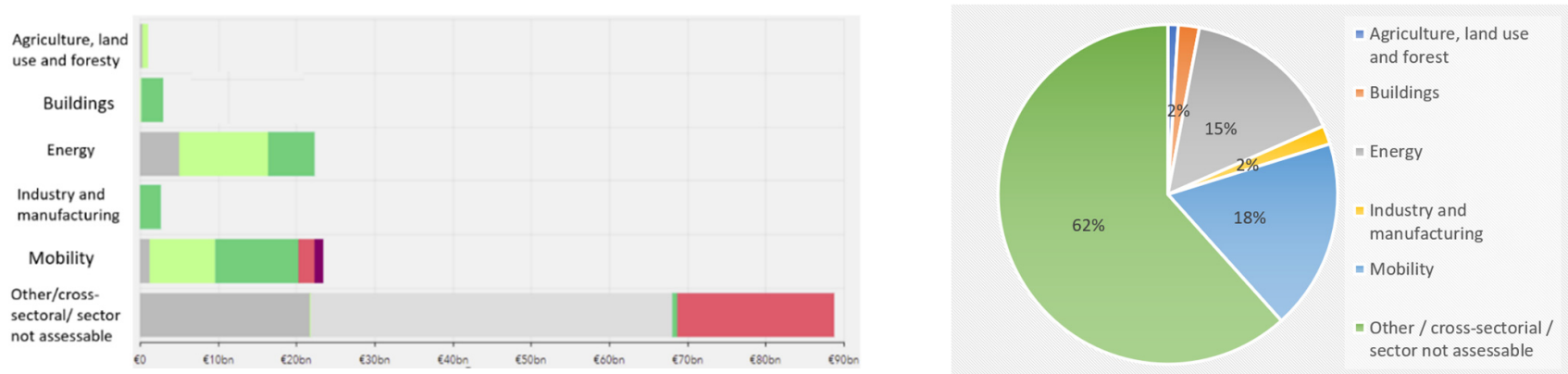

(c)
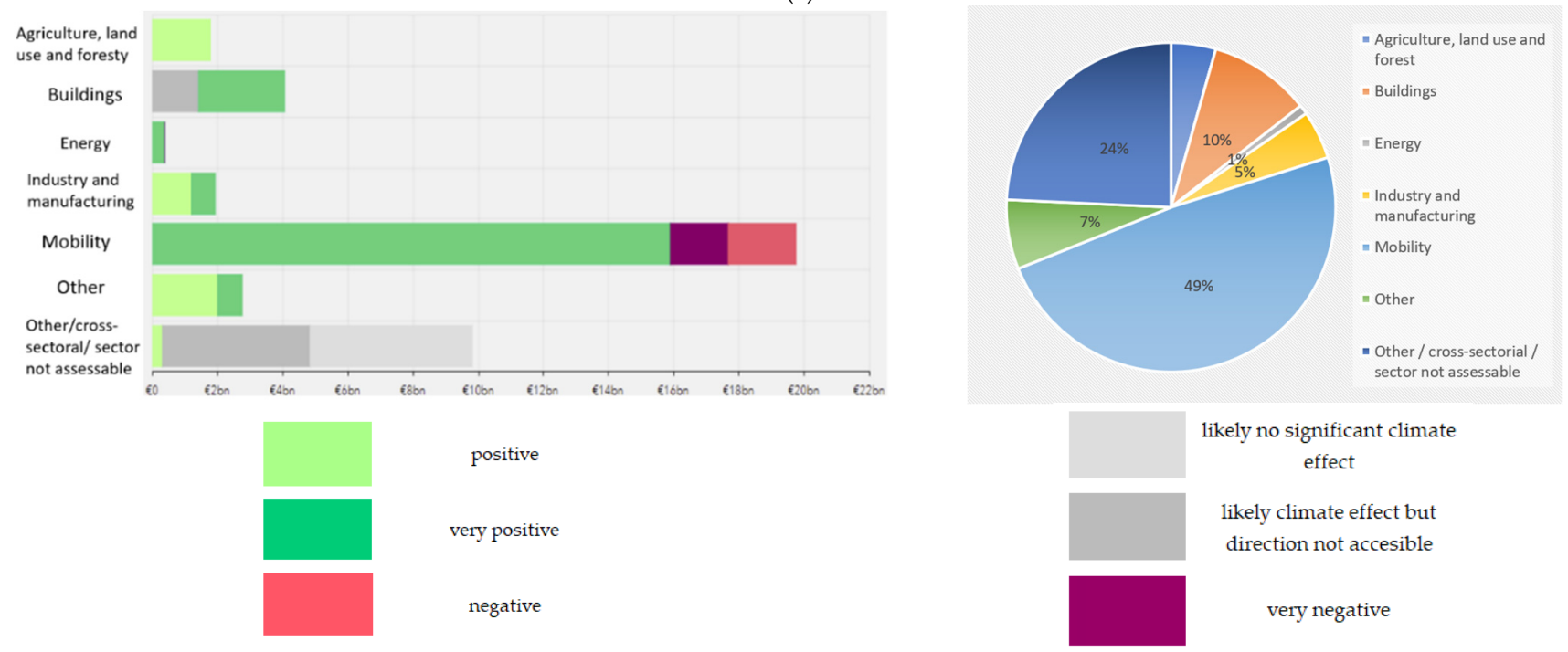

(d)

Figure 3. Comparison of some European Recovery Plans. (a) Spain; (b) France; (c) Germany; (d) Portugal. Source: own elaboration with data from the Green Recovery Tracker, E3G and the Wuppertal Institute [53-58].

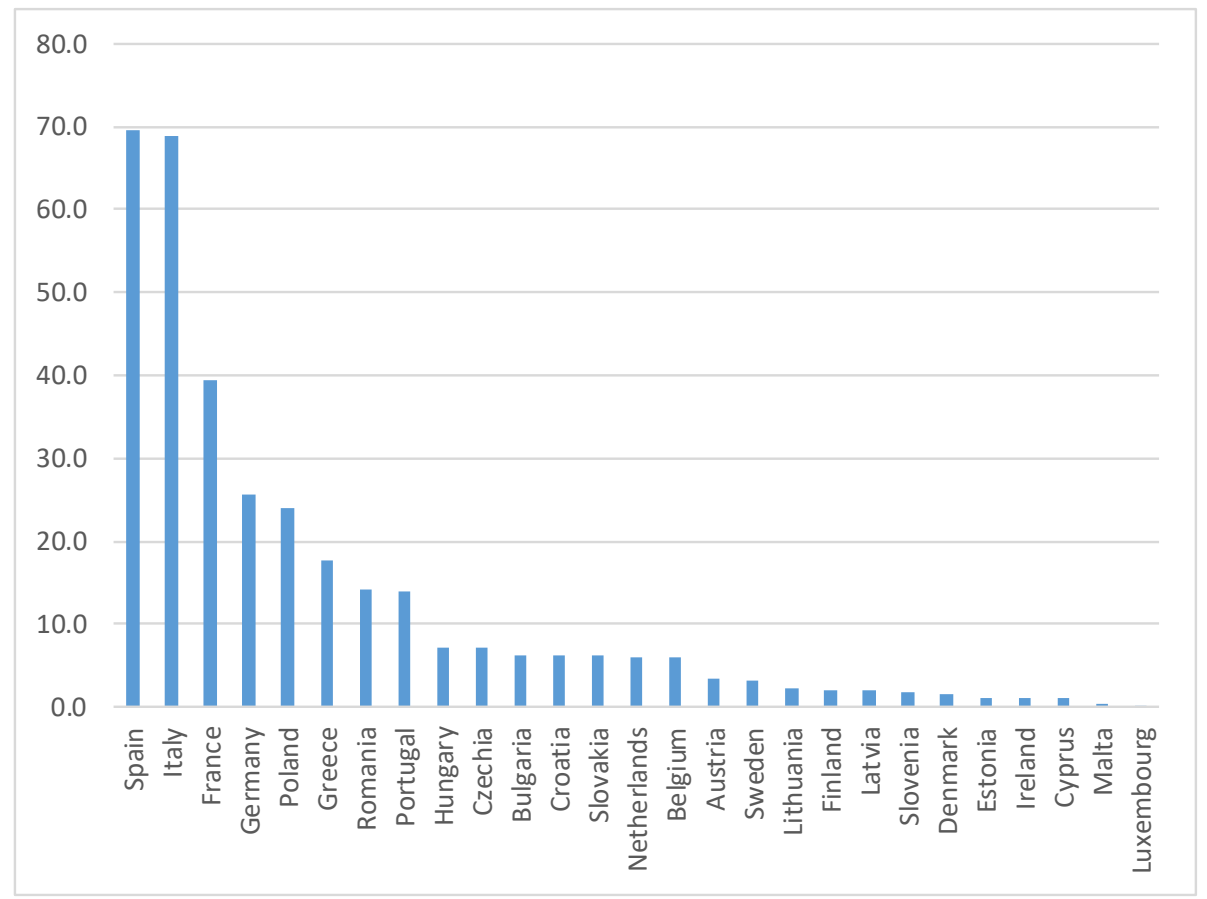

Figure 4. Investments in Recovery and Resilience Plan 2021-2023 (billion euros) by EU country. Source: own elaboration with data from EU member States and the Spanish Recovery Plan [16]. 
Portugal: Investments in nature-based solutions. Portugal's Resilience and Recovery Plan includes EUR 665 million of investments into forest management and cultivation. This measure, which the Environment and Climate Ministry will implement, is presented as an essential resilience measure for rural territories, combining climate change mitigation and long-term resilience. Furthermore, the 2030 Investment Plan contains a further EUR 300 million for maritime biodiversity protection.

Spain: Linking economic recovery and regional development. The Spanish government emphasises supporting less developed regions in the country through its recovery measures aligned with territorial policies, aiming to create more jobs and develop new economic activities in these regions.

\subsubsection{Green Jobs to Generate in Spain}

Using the data provided by the International Energy Agency (IEA) and the International Monetary Fund in this World Energy Outlook [55] (see Figure 5), we have estimated the new green jobs that could be created as a result of the investments made in the Spanish Recovery Plan. We have focused the analysis on the green initiatives of the programs previously stated (see Figure 5 and Table 5). In Table 5 the programmes that will create green jobs are stated, with a calculation that allow to have an idea of the new green jobs created.

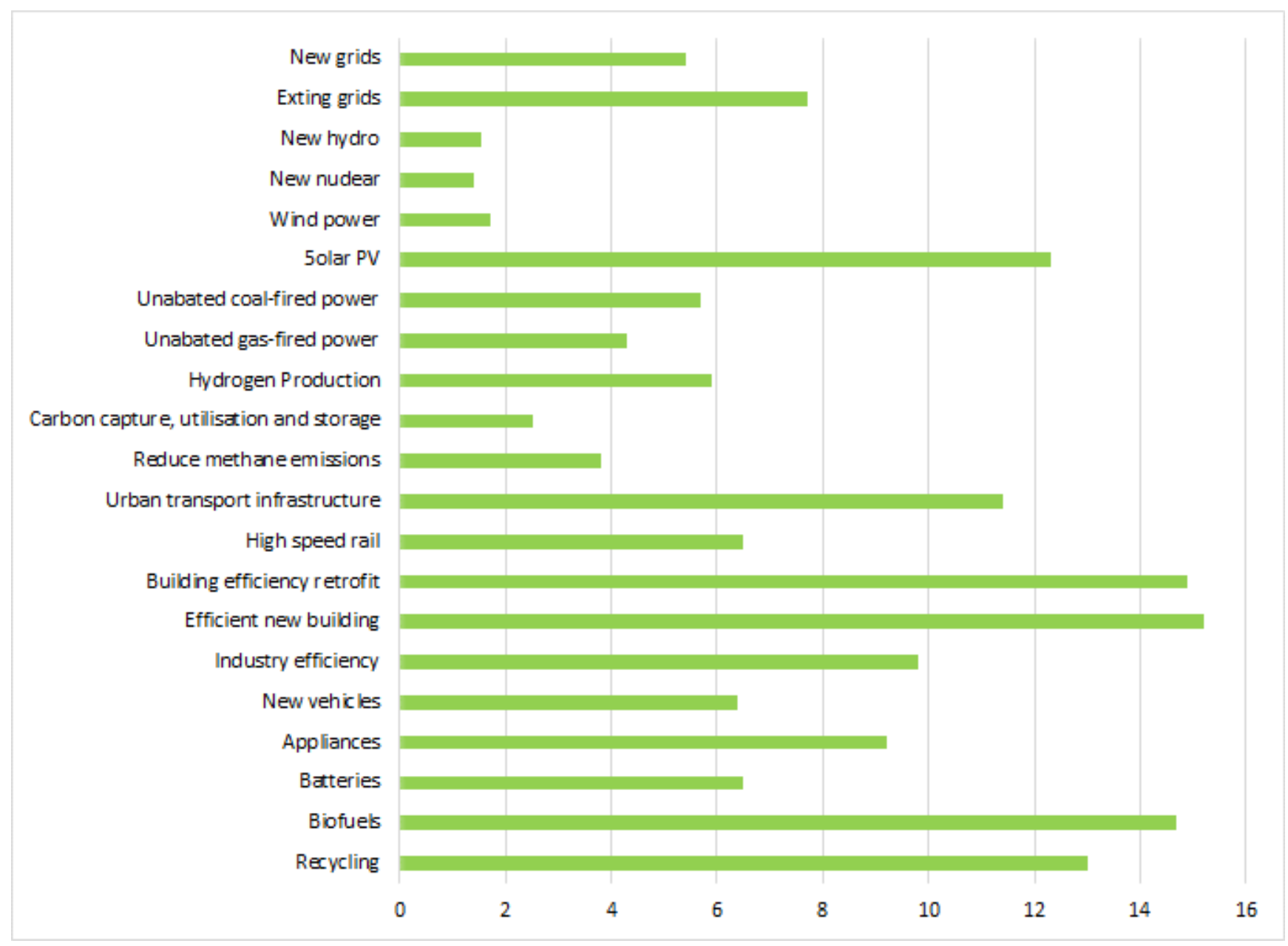

Figure 5. Green jobs generated per million euros invested (x-axis). Source: own elaboration with data from IEA [55].

A first approach with the mentioned methodology, and assuming the investment level per programme along with the corresponding multiplier, the final estimation is approximately 356,000 new green jobs for the period 2021-2023. This first approach should 
be put in context since the following steps are the approval of the green projects that will give them the chance to be implemented to reach the foreseen outcome.

Table 5. Green jobs created and green initiatives. Source: own elaboration with data from IEA [55] and the Spanish Recovery Plan [16].

\begin{tabular}{cccc}
\hline The 20 Programmes Driving Investment & $\begin{array}{c}\text { EUR Billion } \\
\text { 2021-2023 }\end{array}$ & $\begin{array}{c}\text { New Green Jobs/1 } \\
\text { Million Investment }\end{array}$ & $\begin{array}{c}\text { New Green Jobs } \\
\text { Created }\end{array}$ \\
\hline 1. Safe, sustainable and connected mobility strategy & 13.2 & 9.00 & 118,800 \\
2. Housing rehabilitation and urban renewal programme & 6.82 & 15.20 & 103,664 \\
6. New Spain 2030 industrial policy and circular economy strategy & 3.78 & 9.90 & 37,422 \\
9. Development of the national science and innovation system & 3.38 & 8.00 & 27,040 \\
10. Implementation and integration of renewable energies & 3.16 & 6.95 & 21,962 \\
13. Preservation of coastal areas and water resources & 2.09 & 8.00 & 16,720 \\
16. Conservation and restoration of ecosystems and biodiversity & 1.64 & 1.55 & 5.00 \\
17. Renewable hydrogen roadmap & 1.36 & 6.35 & 9145 \\
18. Electrical infrastructure, smart networks and storage & $\mathbf{3 6 . 9 8}$ & 8636 \\
\hline Total Green Initiatives & & $\mathbf{3 5 6 , 5 0 9}$ \\
\hline
\end{tabular}

\subsection{Microeconomics View}

\subsubsection{Green Jobs and Skills}

The primary sources of data and analytics about skills are in the databases and reports of OECD Stats, O*NET and Skills Ovate [33-35,53-58]. The methodology used has been to classify job skills from France, Germany, Italy and Spain, as shown in Table 6. After the individual classification of the most relevant skills by country, we have developed a comparison analysis to detect the skills in which Spain is more deficient than the average (Figure 6).

According to the OECD $[35,57]$ "new Skills for Jobs Indicators" aim "to better adapt to changing skill needs by making available a database of skill imbalances indicators comparable across countries and regularly updated, providing overview and details of the shortages and surpluses of skills across countries".

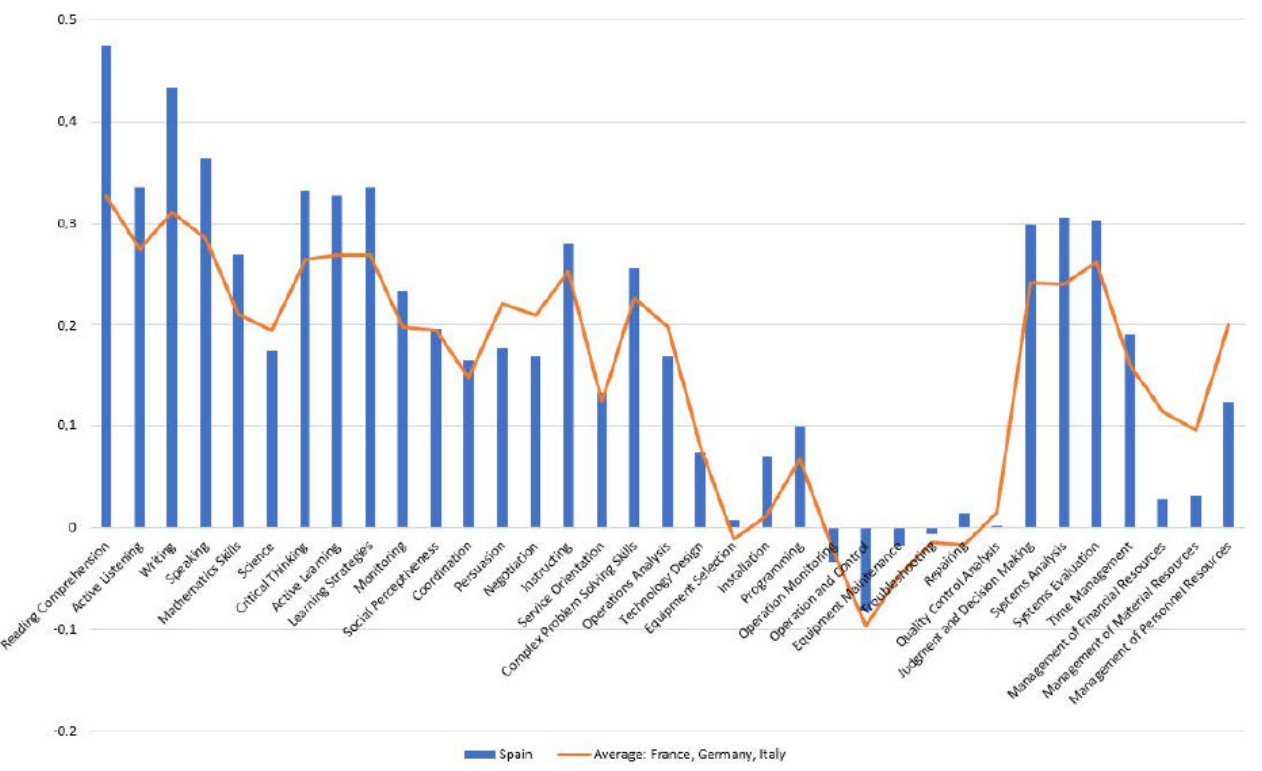

Figure 6. Skills comparison summary. Source: own elaboration with data from OECD data [57]. 
Table 6. Skills comparative view. Source: own elaboration based on data from OECD data [57].

\begin{tabular}{|c|c|c|c|c|c|c|c|c|c|c|c|c|}
\hline \multirow[b]{2}{*}{ Country } & \multirow{2}{*}{$\begin{array}{c}\text { Basic Skills } \\
\text { (Content)—Average }\end{array}$} & \multicolumn{11}{|c|}{ Basic Skills (Content) } \\
\hline & & \multicolumn{2}{|c|}{$\begin{array}{c}\text { Reading } \\
\text { Comprehension }\end{array}$} & \multicolumn{2}{|c|}{ Active Listening } & \multicolumn{2}{|c|}{ Writing } & \multicolumn{2}{|c|}{ Speaking } & \multicolumn{2}{|c|}{$\begin{array}{l}\text { Mathematics } \\
\text { Skills }\end{array}$} & Science \\
\hline France & 0.167 & \multicolumn{2}{|c|}{0.173} & \multicolumn{2}{|c|}{0.167} & \multicolumn{2}{|c|}{0.182} & \multicolumn{2}{|c|}{0.22} & \multicolumn{2}{|c|}{0.109} & 0.153 \\
\hline Germany & 0.259 & \multicolumn{2}{|c|}{0.32} & \multicolumn{2}{|c|}{0.279} & \multicolumn{2}{|c|}{0.3} & \multicolumn{2}{|c|}{0.263} & \multicolumn{2}{|c|}{0.235} & 0.156 \\
\hline Italy & 0.375 & \multicolumn{2}{|c|}{0.487} & \multicolumn{2}{|c|}{0.377} & \multicolumn{2}{|c|}{0.452} & \multicolumn{2}{|c|}{0.37} & \multicolumn{2}{|c|}{0.29} & 0.274 \\
\hline Spain & 0.342 & \multicolumn{2}{|c|}{0.475} & \multicolumn{2}{|c|}{0.335} & \multicolumn{2}{|c|}{0.433} & \multicolumn{2}{|c|}{0.364} & \multicolumn{2}{|c|}{0.269} & 0.175 \\
\hline$\Omega_{2}$ & Basic Skills & & & & & & Basic Skills (P & cess) & & & & \\
\hline Country & (Process)-Average & & ritical Thinking & & & Active Learning & & & earning Strateg & & & \\
\hline France & 0.211 & & 0.166 & & & 0.189 & & & 0.308 & & & \\
\hline Germany & 0.228 & & 0.255 & & & 0.268 & & & 0.223 & & & \\
\hline Italy & 0.311 & & 0.373 & & & 0.349 & & & 0.275 & & & \\
\hline Spain & 0.307 & & 0.332 & & & 0.328 & & & 0.335 & & & \\
\hline & & & & & & & Social Ski & & & & & \\
\hline Country & $\begin{array}{l}\text { Social } \\
\text { Skills-Average }\end{array}$ & Social Pe & ptiveness & Coo & lation & Pers & ion & Nego & ation & Instructing & & \\
\hline France & 0.158 & & & & & & & 0. & & 0.259 & & \\
\hline Germany & 0.228 & & & & & & & 0. & & 0.219 & & \\
\hline Spain & 0.187 & & & & & & & 0. & & 0.28 & & \\
\hline & & & & & & & Technical S & & & & & \\
\hline Country & $\begin{array}{l}\text { Iechnical } \\
\text { Skills-Average }\end{array}$ & $\begin{array}{c}\text { Operations } \\
\text { Analysis }\end{array}$ & $\begin{array}{l}\text { Technology } \\
\text { Design }\end{array}$ & $\begin{array}{c}\text { Equipment } \\
\text { Selection }\end{array}$ & Installation & Programming & $\begin{array}{c}\text { Operation } \\
\text { Monitoring }\end{array}$ & $\begin{array}{l}\text { Operation and } \\
\text { Control }\end{array}$ & $\begin{array}{c}\text { Equipment } \\
\text { Maintenance }\end{array}$ & Troubleshooting & Repairing & $\begin{array}{c}\text { Quality } \\
\text { Control } \\
\text { Analysis }\end{array}$ \\
\hline France & -0.016 & 0.058 & 0.014 & -0.027 & -0.007 & -0.049 & 0.006 & -0.052 & -0.062 & -0.01 & -0.042 & -0.003 \\
\hline Germany & -0.034 & 0.242 & 0.103 & -0.052 & 0.024 & 0.095 & -0.167 & -0.236 & -0.123 & -0.101 & -0.079 & -0.077 \\
\hline Italy & 0.094 & 0.295 & 0.122 & 0.045 & 0.018 & 0.155 & 0.089 & -0.001 & 0.046 & 0.067 & 0.069 & 0.125 \\
\hline Spain & 0.027 & 0.169 & 0.074 & 0.007 & 0.07 & 0.1 & -0.034 & -0.081 & -0.018 & -0.006 & 0.014 & 0.002 \\
\hline Country & & Comp & Problem Solvi & ig Skills-Ave & & & & & Complex Prob & m Solving Skills & & \\
\hline France & & & 0.094 & & & & & & & 994 & & \\
\hline Germany & & & 0.244 & & & & & & & 244 & & \\
\hline Italy & & & 0.341 & & & & & & & 341 & & \\
\hline Spain & & & 0.256 & & & & & & & 256 & & \\
\hline
\end{tabular}


Table 6. Cont

\begin{tabular}{|c|c|c|c|c|c|}
\hline \multirow[b]{2}{*}{ Country } & \multirow{2}{*}{$\begin{array}{c}\text { Resource } \\
\text { Management } \\
\text { Skills-Average }\end{array}$} & \multicolumn{4}{|c|}{ Resource Management Skills } \\
\hline & & Time Management & $\begin{array}{c}\text { Management of } \\
\text { Financial Resources }\end{array}$ & $\begin{array}{c}\text { Management of } \\
\text { Material Resources }\end{array}$ & $\begin{array}{c}\text { Management of } \\
\text { Personnel Resources }\end{array}$ \\
\hline France & 0.169 & 0.17 & 0.124 & 0.144 & 0.238 \\
\hline Germany & 0.1 & 0.089 & 0.104 & 0.062 & 0.145 \\
\hline Italy & 0.159 & 0.222 & 0.113 & 0.082 & 0.219 \\
\hline Spain & 0.093 & 0.191 & 0.028 & 0.031 & 0.124 \\
\hline Country & Systems Skills & Judgment and Decision Making & Syste & \multicolumn{2}{|c|}{ Systems Evaluation } \\
\hline France & 0.133 & 0.143 & & \multicolumn{2}{|c|}{0.139} \\
\hline Germany & 0.263 & 0.247 & & \multicolumn{2}{|c|}{0.291} \\
\hline Italy & 0.348 & 0.335 & & \multicolumn{2}{|c|}{0.355} \\
\hline Spain & 0.302 & 0.299 & & \multicolumn{2}{|c|}{0.302} \\
\hline
\end{tabular}




\subsubsection{Harmonisation and Unit of Measure Used}

According to the methodology used by the OECD [35,57] to classify the different skills by country, the compared results between Spain and the average scores of an average of Germany, France and Italy, are shown on a scale that ranges between -1 and +1 . According to the OECE, "positive values indicate skill shortage, while negative values point to skill surplus. The larger the absolute value, the more significant the imbalance. The maximum value reflects the strongest shortage observed across OECD [35,57] countries and skills dimensions" (see Figure 6).

The skills that must be improved in Spain to adapt generally and for green jobs, according to our analysis and the one provided by the OECD Skills Stats, are the following, as seen in Table 7.

Table 7. Soft skills to improve in Spain. Source: own elaboration based on data from OECD data [57].

\begin{tabular}{|c|c|}
\hline Skill & Skill Above Average \\
\hline Reading Comprehension & - \\
\hline Active Listening & - \\
\hline Writing & - \\
\hline Speaking & - \\
\hline Mathematics Skills & - \\
\hline Science & + \\
\hline Critical Thinking & - \\
\hline Active Learning & - \\
\hline Learning Strategies & - \\
\hline Monitoring & - \\
\hline Social Perceptiveness & - \\
\hline Coordination & - \\
\hline Persuasion & + \\
\hline Negotiation & + \\
\hline Instructing & - \\
\hline Service Orientation & - \\
\hline Complex Problem-Solving & - \\
\hline Operations Analysis & + \\
\hline Technology Design & - \\
\hline Equipment Selection & - \\
\hline Installation & - \\
\hline Programming & - \\
\hline Operation and Control & - \\
\hline Equipment Maintenance & + \\
\hline Troubleshooting & + \\
\hline Repairing & + \\
\hline Judgment and Decision Making & - \\
\hline Systems Analysis & - \\
\hline Systems Evaluation & - \\
\hline Time Management & - \\
\hline Management of financial resources & + \\
\hline Management of material resources & + \\
\hline Management of personnel resources & + \\
\hline
\end{tabular}

Another view of the needed skills is provided by Cedefop Europe [56,58], which classified the skills in a more detailed and visual way.

From both approaches, we may outline a profile of the most required skills, firstly in Spain, and secondly at a European level (see Figure 7). 


\% Share on Total Number of Skill
\begin{tabular}{|l|r|}
\hline Work Output & 15.3 \\
\hline Interacting With Others & 9.4 \\
\hline Mental Processes & 8.3 \\
\hline Adaptability/Flexibility & 6.1 \\
\hline Language & 5.5 \\
\hline Computers and Electronics & 5.3 \\
\hline Cooperation & 4.4 \\
\hline Technology & 4.1 \\
\hline Sales and Marketing & 4.0 \\
\hline Personnel and Human Resources & 2.6 \\
\hline Production and Processing & 2.6 \\
\hline Customer and Personal Service & 2.3 \\
\hline Administration and Management & 2.3 \\
\hline Cognitive Abilities & 2.1 \\
\hline Dependability & 2.1 \\
\hline Resource Management Skills & 2.0 \\
\hline Engineering and Technology & 1.9 \\
\hline Communications and Media & 1.9 \\
\hline Complex Problem Solving Skills & 1.7 \\
\hline Initiative & 1.7 \\
\hline Leadership & 1.6 \\
\hline Independence & 1.1 \\
\hline Mechanical & 1.0 \\
\hline
\end{tabular}

(a)

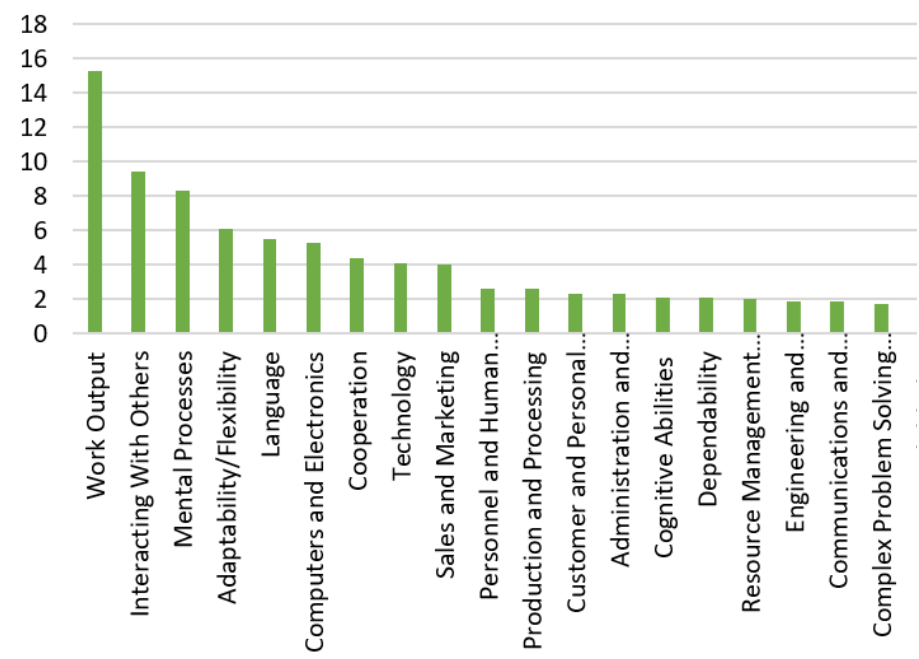

(b)

Figure 7. Percentage share of most important number of skills mentioned; (a) Skills more important in Europe, by number of mentions, Cedefop [56,58]; (b) Graphical view of (a). Source: own elaboration based on data from Cedefop Europe [56,58].

\section{Discussion and Conclusions}

This paper contributes to the understanding and impact of the European Recovery Funds-Recovery and Resilience Facility - on the green industry and, in particular, to the green jobs created (direct and indirect) due to the implementation of the mentioned programme. Furthermore, the work highlights the necessary update of worker skills to carry out those new green jobs requiring a much more skilled labour collaborators (according to WBE).

The first research question formulated-how many estimated new green jobs would be created because of the implementation of the Recovery Plan in Spain-has obtained a specific estimated number of 356,000 green jobs, which exceed the initial expectations planned by the policymakers. This number will be reached in a relatively short period (2021-23) and have included only the Transformation and Resilience Plan presented by Spain and approved by the EU in June 2021. For this purpose, only the Plan's lines of action related to sustainability projects and the creation of green jobs have been considered (with attention to the Ricardo effect or readjustment).

Following the launch of the European Green Deal (EGD) and the temporary halt or slowdown of some economic activities due to the pandemic, and, therefore, of the EGD, the launch of the Recovery and Resilience Facility has meant an injection of special funds that will re-launch the initial EGD more strongly in all EU member countries.

A brief comparison of various countries and their green policies have been made, highlighting the different emphasis placed on different green and non-green investments and projects at the country level. In this respect, it should be noted that a future line of research is to compare all the EU member countries in terms of the evolution of recovery plans, their green policies and the effects these have on the creation of new green jobs. Such work would clearly add value, with a global and country-specific vision, from which all the economies interested in understanding both good practices and success stories (WBE) from other countries would benefit.

As an area for improvement, it should be noted that the present study has been carried out using a diverse range of secondary sources and other research means such as critical and comparative analysis, inductive and deductive reasoning and some mathematical calculations for the calculation of green jobs. Although it is based on the Leontief inputoutput model, this has been applied indirectly through surveys and disaggregated data, 
albeit from other countries. A subsequent study will use primary sources that allow a more satisfactory adjustment to be made at a national and sector level within the green sector and others associated. Additionally, the novelty of the Recovery Plan means that empirical data about the behaviour of the different projects are not yet available as they have not been implemented. This newness has been especially noted in the lack of literature on the subject. As countries start implementing their respective Recovery Plans, much more information will be released to conduct more profound and more precise abundant research.

Regarding the second research question-which new soft skills or re-skilling would be necessary to develop the new green jobs created under the Plan, in the case of Spain-some interesting points have come to light. This question has highlighted the vast diversity of different general job skills, as pointed out by international organisations. However, after a general comparison between other countries and the Spanish case, the skills profile of Spanish workers is below the OECD average in basic cognitive skills, complex problem solving, critical thinking or innovative capacity. As the lack of general soft skills is identified, it would be in the best interest of policymakers, companies and workers to have a clear profile of the green skills required for the foreseen thousands of new jobs to be generated (linked to WBE).

Finally, the challenge to realise a plan with so many lines of implementation must be taken into account, as well as the risk associated with the rapid and constant evolution and changes that will occur in the respective green projects of the Recovery Plan, which can significantly affect the impact on green jobs and the need to incorporate alternative contingency and management plans.

Author Contributions: Conceptualisation, M.G.V. and A.S.-B.; investigation, M.G.V., A.S.-B. and J.L.; writing—original draft preparation, M.G.V. and A.S.-B.; writing—review and editing, M.G.V., A.S.-B. and J.L.; supervision, M.G.V., A.S.-B. and J.L. All authors have read and agreed to the published version of the manuscript.

Funding: This research received no external funding.

Institutional Review Board Statement: Not applicable.

Informed Consent Statement: Not applicable.

Data Availability Statement: Not applicable.

Acknowledgments: To GESCE—URJC, GID—TICTAC CCEESS—URJC and TRANS-REAL LAB_UVA.

Conflicts of Interest: The authors declare no conflict of interest.

\section{References}

1. Sánchez-Bayón, A. Renewal of business \& economic thought after the globalization. Bajo Palabra 2020, 24, 293-318. [CrossRef]

2. Intergovernmental Panel on Climate Change. In Managing the Risks of Extreme Events and Disasters to Advance Climate Change Adaptation: Special Report of the Intergovernmental Panel on Climate Change; Cambridge University Press: Cambridge, UK, 2012.

3. SDG agenda 2030. Transforming our World. The 2030 Agenda for Sustainable Development I Department of Economic and Social Affairs. Available online: Un.org (accessed on 15 May 2021).

4. OECD. The Economy of Well-Being. The Economy of Well-Being-OECD. Available online: https://www.oecd.org/ officialdocuments / publicdisplaydocumentpdf / ?cote=SDD /DOC(2019)2\&docLanguage=En\#: \{\}:text=The\%20\%E2\%80\% 9CEconomy\%20of\%20Well\%2Dbeing,2 (accessed on 15 May 2021).

5. WEF. Wellbeing Economy Alliance. About-Wellbeing Economy Alliance. Available online: https://wellbeingeconomy.org (accessed on 15 May 2021).

6. European Commission. European Green Deal. A European Green Deal-European Commission. Available online: Europa.eu (accessed on 15 May 2021).

7. European Parliament. Multiannual Finance Framework. El Marco Financiero Plurianual—Fichas Temáticas Sobre la Unión Europea-Parlamento Europeo. Available online: Europa.eu (accessed on 15 May 2021).

8. European Commission. The European Green Deal COM/2019/640 Final. Available online: https:/ / eur-lex.europa.eu/legalcontent/EN/TXT/?uri=COM\%3A2019\%3A640\%3AFIN (accessed on 15 May 2021).

9. Heredia Yzquierdo, J.; Sánchez-Bayón, A. The European transition to a green energy production model: Italian feed-in tariffs scheme \& Trentino Alto Adige mini wind farms case study. Small Bus. Int. Rev. 2020, 4, 39-52. [CrossRef]

10. Sánchez-Bayón, A.; Trincado, E. Business and labour culture changes in digital paradigm. Cogito 2020, 12, 225-243. 
11. Taleb, N.N. The Black Swan: The Impact of the Highly Improbable; Ramdom House: New York, NY, USA, 2007.

12. Bagus, P.; Peña-Ramos, J.A.; Sánchez-Bayón, A. COVID-19 and the Political Economy of Mass Hysteria. Int. J. Env. Res. Public Health 2021, 18, 1376. [CrossRef] [PubMed]

13. de Soto, J.H.; Sánchez-Bayón, A.; Bagus, P. Principles of Monetary \& Financial Sustainability and Wellbeing in a Post-COVID-19 World: The Crisis and Its Management. Sustainability 2021, 13, 4655. [CrossRef]

14. European Commission. Recovery Plan for Europe. Available online: https://ec.europa.eu/info/strategy/recovery-plan-europe_ en (accessed on 15 May 2021).

15. EUR-Lex. Regulation (EU) 2021/241 of the European Parliament and of the Council of 12 February 2021 Establishing the Recovery and Resilience Facility. 2021. Available online: https:/ / eur-lex.europa.eu/legal-content/EN/TXT/?uri=CELEX\%3A32021R0241 (accessed on 15 May 2021).

16. Vicepresidencia del Gobierno y Ministerio de Asuntos Económicos y Transformación Digital. Plan de Recuperación, Transformación y Resiliencia. Available online: https://portal.mineco.gob.es/es-es/ministerio/areas-prioritarias/Paginas/ PlanRecuperacion.aspx (accessed on 15 May 2021).

17. International Labour Organization (ILO). What Is a Green Job? Available online: https://www.ilo.org/global/topics/greenjobs/news/WCMS_220248/lang--en/index.htm (accessed on 15 May 2021).

18. Eur-Lex. Proposal for a Regulation of the European Parliament and the Council Establishing the Framework for Achieving Climate Neutrality and Amending Regulation (EU) 2018/1999 (European Climate Law). Available online: https:/ / eur-lex.europa. eu/legal-content/EN/TXT/?qid=1588581905912\&uri=CELEX:52020PC0080 (accessed on 15 May 2021).

19. Ecologic-EU. Climate Laws in Europe. Good Practices in Net-Zero Management. Available online: Ecologic.eu (accessed on 15 May 2021).

20. European Commission. Developing a Sustainable Blue Economy in the European Union. Available online: https://ec.europa.eu/ commission/presscorner/detail/en/ip_21_2341 (accessed on 15 May 2021).

21. European Commission. Towards Zero Pollution for Air, Water and Soil. Available online: https://ec.europa.eu/commission/ presscorner/detail/en/ip_21_2345 (accessed on 15 May 2021).

22. European Commission. Organic Action Plan. Available online: https://ec.europa.eu/info/food-farming-fisheries/farming/ organic-farming/organic-action-plan_en (accessed on 15 May 2021).

23. Sánchez-Bayón, A. Fundamentos de Derecho Comparado y Global: ¿cabe un orden común en la globalización? Boletín Mex. Derecho Comp. 2014, 141, 1021-1051. [CrossRef]

24. International Labour Organization (ILO). Guidelines for a Just Transition towards Environmentally Sustainable Economies and Societies for All. Available online: https://www.ilo.org/global/topics/green-jobs/publications/WCMS_432859/lang--en/index. htm (accessed on 15 May 2021).

25. Sánchez-Bayón, A.; García-Vaquero, M.; Lominchar, J. Wellbeing Economics: Beyond the Labour compliance \& challenge for business culture. J. Leg. Ethical Regul. Issues 2021, 24, 1-15.

26. Bowen, A.; Kuralbayeva, K.; Tipoe, E.L. Characterizing green employment: The impacts of 'greening' on workforce composition. Energy Econ. 2018, 72, 263-275. [CrossRef]

27. Consoli, G.; Marin, A.; Marzucchi, A.; Vona, F. Do green jobs differ from non-green jobs in terms of skills and human capital? Res. Policy 2016, 45, 1046-1060. [CrossRef]

28. Lobisger, M.; Rutzer, C. Jobs with Green Potential in Switzerland: Demand and Possible Skills Shortages Jobs with Green Potential in Switzerland: Demand and Possible Skills Shortages; WWZ Working Papers-University of Basel: Basel, Switzerland, 2021.

29. Martínez-Fernández, C.; Hinojosa, C.; Miranda, G. Green Jobs and Skills: The Local Labour Market Implications of Addressing Climate Change. Working Document-CFE/LEED-OECD. 2010. Available online: www.oecd.org/dataoecd/54/43/44683169.pdf? contentId=44683170 (accessed on 15 May 2021).

30. UK Office of National Statistics. The Challenges of Defining a "Green Job". Available online: https://www.ons.gov.uk/economy/ environmentalaccounts/methodologies/thechallengesofdefiningagreenjob (accessed on 15 May 2021).

31. Eurostat. Environmental Economy Statistics on Employment and Growth. Available online: https://ec.europa.eu/eurostat/ statistics-explained/index.php?title=Environmental_economy_--_statistics_on_employment_and_growth (accessed on 15 May 2021).

32. US Bureau of Labor Statistics. Measuring Green Jobs. Available online: https://www.bls.gov/green/home.htm (accessed on 15 May 2021).

33. O*NET. U.S. Department of Labour. Available online: https://www.onetcenter.org/dictionary/22.0/excel/green_occupations. html (accessed on 15 May 2021).

34. O*NET Online. Available online: https:/ / www.onetonline.org (accessed on 15 May 2021).

35. OECD. Towards Green Growth. 2021. Available online: https://www.oecd.org/greengrowth/48012345.pdf (accessed on 15 May 2021).

36. European Commission. Basics Green Economy [WWW Document]. 2016. Available online: http://ec.europa.eu/environment/ basics/green-economy/resources /index_en.htm (accessed on 15 May 2021).

37. World Bank. Inclusive Green Growth, the Pathway to Sustainable Development. 2012. Available online: worldbank.org (accessed on 15 May 2021). 
38. UNEP. Towards a Green Economy: Pathways to Sustainable Development and Poverty Eradication. 2011. Available online: https:/ / sustainabledevelopment.un.org/index.php?page=view\&type=400\&nr=126\&menu=35 (accessed on 15 May 2021).

39. Grand, M.C. Carbon emission targets and decoupling indicators. Ecol. Indic. 2016, 67, 649-656. [CrossRef]

40. Tapio, P. Towards a theory of decoupling: Degrees of decoupling in the EU and the case of road traffic in Finland between 1970 and 2001. Transp. Policy 2005, 12, 137-151. [CrossRef]

41. Akizu-Gardoki, O.; Bueno, G.; Wiedmann, T.; Lopez-Guede, J.M.; Arto, I.; Hernandez, P.; Moran, D. Decoupling between human development and energy consumption within footprint accounts. J. Clean. Prod. 2018, 202, 1145-1157. [CrossRef]

42. Bithas, K.; Kalimeris, P. Unmasking decoupling: Redefining the Resource Intensity of the Economy. Sci. Total Environ. 2018, 619, 338-351. [CrossRef] [PubMed]

43. Bonaiuti, M. Are we entering the age of involuntary degrowth? Promethean technologies and declining returns of innovation. J. Clean. Prod. Technol. Degrowth 2018, 197, 1800-1809. [CrossRef]

44. Moreau, V.; Vuille, F. Decoupling energy use and economic growth: Counter evidence from structural effects and embodied energy in trade. Appl. Energy 2018, 215, 54-62. [CrossRef]

45. O’Neill, D.W.; Fanning, A.L.; Lamb, W.F.; Steinberger, J.K. A good life for all within planetary boundaries. Nat. Sustain. 2018, 1, 88. [CrossRef]

46. EEA. Trends and Projections in Europe 2018. In Tracking Progress towards Europe's Climate and Energy Targets (No. 16/2018); European Environment Agency: Copenhagen, Denmark, 2018.

47. European Commission. A Clean Planet for All. In A European Strategic Long-Term Vision for a Prosperous, Modern, Competitive and Climate Neutral (COM No. 773); European Commission: Brussels, Belgium, 2018.

48. VV.AA. Defining a New Economic Paradigm: The Report of the High-Level Meeting on Wellbeing and Happiness. 2012. Available online: https: / / sustainabledevelopment.un.org/index.php?page=view\&type=400\&nr=617\&menu=35 (accessed on 15 May 2021).

49. World Happiness Report 2020. 2020. Available online: https://s3.amazonaws.com/happiness-report/2020/WHR20.pdf (accessed on 15 May 2021).

50. Sánchez-Bayón, A. A history of HR and its digital transformation: From Fordism to talentism and happiness management. Rev Asoc. Española Espec. Med. Trab. 2020, 29, 198-214.

51. Nordstrom, K.; Ridderstrale, J. Funky Business: Talent Makes Capital Dance; Pitman Publishing: London, UK, 2000.

52. Cubeiro, J.L. Del Capitalismo al Talentismo; University of Deusto: Bilbao, Spain, 2012.

53. European Commission. Recovery and Resilience Facility. Available online: https://ec.europa.eu/info/business-economy-euro/ recovery-coronavirus/recovery-and-resilience-facility_en (accessed on 15 May 2021).

54. E3G and Wuppertal Institute. Green Recovery Tracker. Available online: https://experience.arcgis.com/experience/f2700c9b597 a4aababa4c80e732c6c5c/page/page_13/?views=view_16 (accessed on 15 May 2021).

55. IEA and International Monetary Fund. Sustainable Recovery: World Energy Outlook. Sustainable Recovery—Analysis—IEA. Available online: https:/ /iea.blob.core.windows.net/assets/c3de5e13-26e8-4e52-8a67-b97aba17f0a2/Sustainable_Recovery.pdf (accessed on 15 May 2021).

56. Skills-OVATE. Skills Online Vacancy Analysis Tool for Europe. Available online: https://www.cedefop.europa.eu/en/datavisualisations / skills-online-vacancies/skills / occupations (accessed on 15 May 2021).

57. OECD. Skills Statistics by Country STAT. 2018. Available online: https://stats.oecd.org/Index.aspx?DataSetCode=SKILLS_2018 TOTAL\# (accessed on 15 May 2021).

58. CEDEFOP. Skills for Green Jobs. Skills for Green Jobs: 2018 Update Cedefop. Available online: europa.eu (accessed on 15 May 2021).

59. Sikora, A. European Green Deal—Legal and Financial Challenges of Climate Change. ERA Forum 2021, 4, 681-697. [CrossRef]

60. Sulich, A.; Rutkowska, M.; Pop, L. Green jobs, definitional issues, and the employment of young people: An analysis of three European Union countries. J. Jenvman 2020, 262. [CrossRef] [PubMed]

61. Dell'Anna, F. Green jobs and energy efficiency as strategies for economic growth and the reduction of environmental impacts. Energy Policy 2021, 149. [CrossRef] 